Review

\title{
Configuration Development of Autothermal Solid Oxide Fuel Cell: A Review
}

\section{Pannipha Dokmaingam}

School of Health Science, Mae Fah Luang University, Chiang Rai 57100, Thailand E-mail:dpannipha@gmail.com

\begin{abstract}
Solid Oxide Fuel Cell (SOFC) is typically operated at high temperature. Both electricity and heat are generated during operation. Therefore, SOFC can be efficiently designed to integrate the endothermic reformer with the cell for optimizing heat utilization, as called autothermal operation. However, the mismatch between rate of exothermic electrochemical reaction and endothermic reforming reaction is easily resulted in material cracking of that integrated structure. In order to overcome the thermal mismatch limitation, various approaches for autothermal SOFC configurations have been widely developed; these configurations can be classified into 2 main groups including direct internal reforming (as called DIR-SOFC) and indirect internal reforming (as called IIR-SOFC) operations. This review focuses on the technological progress of these various configurations. In detail, the thermal behavior inside each autothermal SOFC configuration is explored. The effect of different primary hydrocarbon fuels on temperature distribution in the autothermal SOFC structures is also indicted. In addition, the advantage and disadvantage on thermal stress reduction of each configuration are also discussed. The historical of this development would advantage for further system modification and scale up to desired power output
\end{abstract}

Keywords: Autothermal, SOFC, DIR, IIR.

ENGINEERING JOURNAL Volume 19 Issue 2

Received 9 June 2014

Accepted 8 October 2014

Published 30 April 2015

Online at http://www.engj.org/

DOI:10.4186/ej.2015.19.2.1 


\section{Introduction}

Historically, the fuel cell technology has been introduced as alternative power generation technology for long time. This technology is developed to generate electricity via electrochemical reaction. Base on operating condition, it can be separated into: high-temperature fuel cell and low-temperature fuel cell. Operating temperature of high-temperature fuel cell is around $873-1273 \mathrm{~K}$, such as molten carbonate fuel cell (MCFC), and solid oxide fuel cell (SOFC). Meanwhile, the operating temperature of low-temperature fuel cell is not higher than $393 \mathrm{~K}$, such as alkaline fuel cell (AFC), proton exchange membrane (PEM) fuel cell [1]. For stationary power station application, the high temperature fuel cell is more preferable. This might be resulted of toughness of electrodes and electrolyte material, and system efficiency. One of famous high temperature fuel cell is SOFC. It is made from porous ceramic electrodes and a solid oxide electrolyte. During SOFC operation, both power and heat are also generated. Therefore, the exothermic SOFC is designed to integrate with endothermic reformer for optimizing heating utilization, as called autothermal operation. However, the mismatch between rate of exothermic electrochemical reaction and endothermic reforming reaction generated the thermal stress in the solid material. The residual stress resulted in material cracking of those integrated structure $[2,3]$. The durability of material is directly affected the cost of autothermal SOFC technology. Thus, the thermal mismatch limitation should be overcome for commercial application. One of interesting solutions is integrated configuration of the autothermal SOFC technology. Theoretically, the autothermal SOFC reactor could be designed into 2 approaches: direct internal reforming SOFC (DIR-SOFC) and indirect internal reforming SOFC (IIR-SOFC).

Although there are many review article about SOFC technology during past 5 years [1, 4-12], most of them review about the SOFC material and fabrication technology, material synthesis and testing techniques, simulation technique, and design of SOFC. Meanwhile this publication focuses on the thermal behavior of various autothermal SOFC configurations. The development of both DIR-SOFC and IIR-SOFC patterned had been reviewed since the earlier state of the technology. The advantage and disadvantage on thermal stress reduction of each configuration are also discussed. Note that, the thermal behavior has been investigated by using computer simulation technique. The historical of this development would advantage for further system modification and scale up to desired power output.

\section{Electrical Generation Mechanism in SOFC}

SOFC is a power generation system which directly converts chemical energy to electrical energy. Each single cell consists of porous ceramic electrodes and a solid ceramic electrolyte. Commonly, anode, cathode and electrolyte materials are Ni/YSZ, perovskite-based $\mathrm{LaMnO}_{3}$ and yttria-stabilized zirconia (YSZ), respectively [4]. Series of SOFC are developed for stationary applications with an output from $1 \mathrm{~kW}$ to 2 MW. They are operated at high temperatures $\left(973-1273^{\circ} \mathrm{C}\right)[13,14]$ and at atmospheric or raised pressures. It should be note that power generation process of fuel cells is different from the conventional internal combustion engines. In the internal combustion engines, chemical energy has to be converted to mechanical energy before generating electricity. Meanwhile, the chemical energy is converted directly to power in the case of fuel cells. According to the principle mechanism of SOFC, fuel is oxidized to generate electricity via electrochemical reactions, Eqs. (1)-(4). As shown in Fig. 1, hydrogen $\left(\mathrm{H}_{2}\right)$ and carbon monoxide (CO) are fed into SOFC as fuel while oxygen $\left(\mathrm{O}_{2}\right)$ is used as oxidant at the cathode. The oxygen gas is reduced to oxygen ion. The oxygen ion is transmitted from the cathode through the solid electrolyte to the anode and then the ion is oxidized with $\mathrm{H}_{2}$ and $\mathrm{CO}$, simultaneously. After that water $\left(\mathrm{H}_{2} \mathrm{O}\right)$, carbon dioxide $\left(\mathrm{CO}_{2}\right)$ and electrons are generated over electrocatalyst, Eqs. (1)-(3). However, electrons cannot travel though electrolyte to cathode, they go via an external circuit, resulting in an electric current [15]. It should be noted that both $\mathrm{H}_{2}$ and $\mathrm{CO}$ could be the feedstock for SOFC. Therefore, the overall reactions in the system will liberate $\mathrm{H}_{2} \mathrm{O}, \mathrm{CO}_{2}$ and heat. Furthermore. The $\mathrm{O}_{2}$ should be fed more than theoretical stoichiometry in order to ensure that the overall electrochemical reaction is completed.

For the actual power usage, it is necessary to combine single cells together in stack. Typically, the SOFC is fabricated into two geometries: planar, Fig. 2(a), and tubular, Fig. 2(b). The benefits of tubular design are feasible for large scale application and ease to seal $[16,17]$. On the other hand, the advantages of the planar design are manufacture, stacking and system efficiency [17].

Electrochemical reactions in SOFC:

Cathode reaction: $\quad \mathrm{O}_{2}+4 \mathrm{e}^{-} \rightarrow 2 \mathrm{O}^{2-}$ 
$\begin{array}{ll}\text { Anode reaction: } & \mathrm{H}_{2}+\mathrm{O}^{2-} \rightarrow \mathrm{H}_{2} \mathrm{O}+2 \mathrm{e}^{-} \\ & \mathrm{CO}+\mathrm{O}^{2-} \rightarrow \mathrm{CO}_{2}+2 \mathrm{e}^{-} \\ \text {Overall reaction: } & \mathrm{H}_{2}+\mathrm{CO}+\mathrm{O}_{2} \rightarrow \mathrm{H}_{2} \mathrm{O}+\mathrm{CO}_{2}\end{array}$

$$
\mathrm{H}_{2}+\mathrm{CO}+\mathrm{O}_{2} \rightarrow \mathrm{H}_{2} \mathrm{O}+\mathrm{CO}_{2}
$$

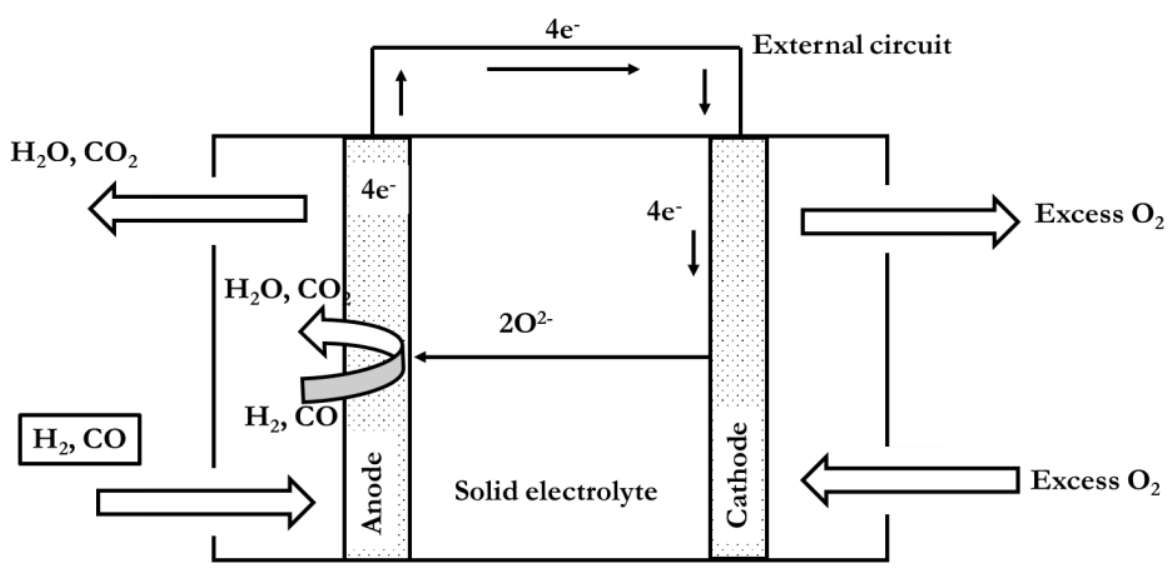

Fig. 1. SOFC operation.

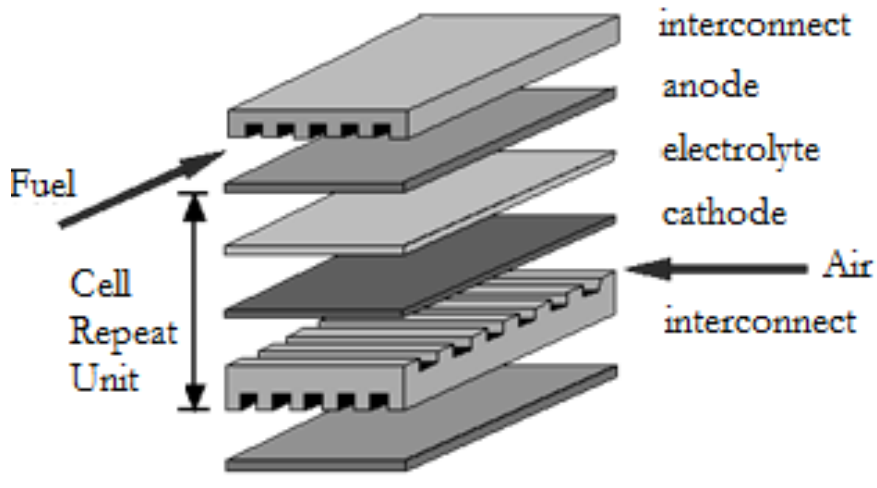

(a) Planar design

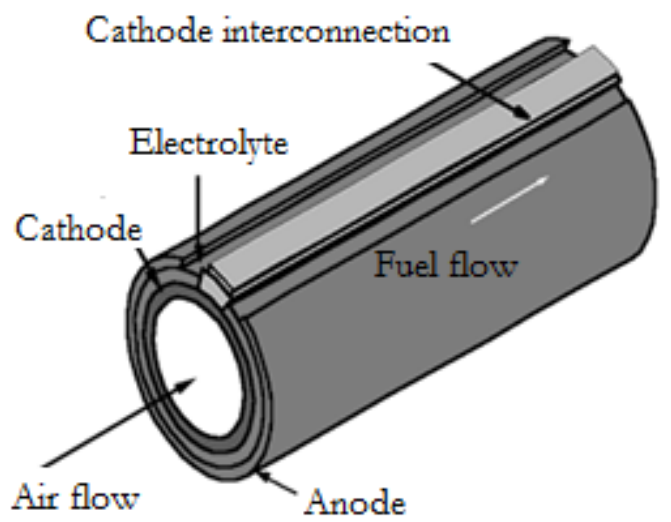

(b) Tubular design

Fig. 2. Typical designs for solid oxide fuel cell stacks: (a) Planar design [18]; (b) Tubular design [18].

Moreover, fuel cell is actually operated, its electrochemical reaction is irreversible so the exciting voltage is normally less than the theoretical value of the open circuit voltage. This is the result of ohmic, activation and concentration polarization. The typicality of the high temperature fuel cell is shown in Fig. 3.

- Ohmic polarization results from electrode and electrolyte resistance to the electron and ion flow. This is specific to types of electrodes and electrolyte materials and current density during operation $[15,19-20]$.

- Activation polarization is the effect of activation barrier of electrochemical reaction at the electrode. This effect becomes more significant when current density is lower. The overpotential can be evaluated by the Butler-Volmer equation [15]. Several literatures of SOFC modelling suggested that this equation is suitable to explain the activation behavior without error [21, 22].

- Concentration polarization is the result of the drop in pressure or partial pressure of reactant gases along the electrodes at the reaction sites. Thus, porosity of electrodes materials is the main parameters for reactant gases diffusibility. However, this overpotential is normally reduced at high current density $[15,19-20]$.

Generally, gas diffusion behavior will be explained by three mathematical models: Fick's model, Dusty gas model, and Stefan-Maxwell model. According to the work of Suwanwarangkul et al.[23], The dusty gas model was recommended to calculate gas diffusion at the anode of SOFC system. This suggestion was confirmed by Pacheco et al.[21] Nevertheless, Fick's model and Stefan-Maxwell model are still applied in some SOFC models. 


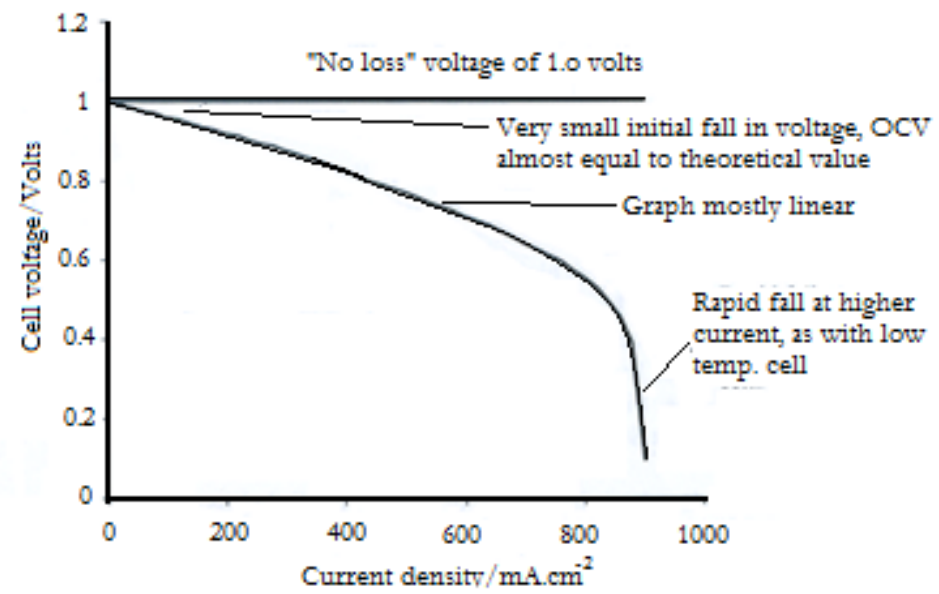

Fig. 3. The voltage of a typical air pressure fuel cell operating at about $800^{\circ} \mathrm{C}$ [15].

\section{Solid Oxide Fuel Cell Reforming Concept}

The autothermal operation has been of interest in education and industry during the last decade [24]. Integration of regenerative and recuperative heat exchanger and reactor within one part of the equipment is the main concept of this operation. Its advantages are heat loss minimization and the less sensitivity to perturbations due to its natural adaptive [25]. This concept is also applied to optimize heat use between reformer and SOFC.

In the case of SOFC technology, the primary fuels (hydrocarbon compounds) have to be reformed into hydrogen rich gas before being fed into the cell. The famous primary fuels are methane, methanol and ethanol. These are normally reformed via various reactions such as steam reforming, water gas shift, decomposition or partial oxidation.

\section{Reforming of Methane}

Generally, hydrogen can be produced from methane via several processes, as expressed in Eqs. (5)-(8). Furthermore, it should be noted that the associated water-gas shift reaction is formed in steam reforming process.

$$
\begin{array}{ll}
\text { Methane steam reforming: } & \mathrm{CH}_{4}+\mathrm{H}_{2} \mathrm{O} \leftrightarrow 3 \mathrm{H}_{2}+\mathrm{CO} ; \Delta \mathrm{H}_{\mathrm{rxn}}=206 \mathrm{~kJ} / \mathrm{mol} \\
\text { Water-gas shift reaction: } & \mathrm{CO}+\mathrm{H}_{2} \mathrm{O} \leftrightarrow \mathrm{H}_{2}+\mathrm{CO}_{2} ; \Delta \mathrm{H}_{\mathrm{rxn}}=-41 \mathrm{~kJ} / \mathrm{mol} \\
\text { Dry Reforming: } & \mathrm{CH}_{4}+\mathrm{CO}_{2} \rightarrow 2 \mathrm{H}_{2}+2 \mathrm{CO} ; \Delta \mathrm{H}_{\mathrm{rxn}}=247 \mathrm{~kJ} / \mathrm{mol} \\
\text { Partial Oxidation: } & \mathrm{CH}_{4}+0.5 \mathrm{O}_{2} \rightarrow 2 \mathrm{H}_{2}+\mathrm{CO} ; \Delta \mathrm{H}_{\mathrm{rxn}}=-38 \mathrm{~kJ} / \mathrm{mol}
\end{array}
$$

where $\Delta \mathrm{H}_{\mathrm{rxn}}$ is heat of reaction.

During the past decade, Ni-based catalysts, such as $\mathrm{Ni} / \mathrm{MgAl}_{2} \mathrm{O}_{4}$ [26] $\mathrm{Ni} / \gamma \mathrm{Al}_{2} \mathrm{O}_{3}$ [27], Ni/YSZ [28-29] and $\mathrm{K}_{2} \mathrm{Tix} \mathrm{O} y-\mathrm{Al}_{2} \mathrm{O}_{3}[30]$, were widely utilized in methane steam reforming (MSR) processes. Other material was also synthesised for methane stream reforming reaction for example: ceria-zirconia supported rhodium [31].

\section{Reforming of Methanol}

Methanol is also attractive for produce hydrogen. According to this process, the thermodynamics of these key reactions, Eqs. (9)-(12), are important to consider [32].

Methanol steam reforming:

Methanol decomposition:

Water gas shift:

Partial oxidation:

$$
\begin{aligned}
& \mathrm{CH}_{3} \mathrm{OH}+\mathrm{H}_{2} \mathrm{O} \leftrightarrow 3 \mathrm{H}_{2}+\mathrm{CO}_{2} ; \Delta \mathrm{H}_{\mathrm{rxn}}=247 \mathrm{~kJ} / \mathrm{mol} \\
& \mathrm{OH} \leftrightarrow 2 \mathrm{H}_{2}+\mathrm{CO} ; \Delta \mathrm{H}_{\mathrm{rxn}}=90.64 \mathrm{~kJ} / \mathrm{mol} \\
& \mathrm{CO}+\mathrm{H}_{2} \mathrm{O} \leftrightarrow \mathrm{H}_{2}+\mathrm{CO}_{2} ; \Delta \mathrm{H}_{\mathrm{rxn}}=-41 \mathrm{~kJ} / \mathrm{mol} \\
& \mathrm{CH}_{3} \mathrm{OH}+0.5 \mathrm{O}_{2} \leftrightarrow 3 \mathrm{H}_{2}+\mathrm{CO} ; \Delta \mathrm{H}_{\mathrm{rxn}}=20 \mathrm{~kJ} / \mathrm{mol}
\end{aligned}
$$

Methanol has been applied as a primary fuel for fuel cells since the early days of fuel cell development. For methanol steam reforming, copper $(\mathrm{Cu})$ is generally used as a catalyst. Since the reforming temperature of $\mathrm{Cu}$ catalysts are typically in the range of $433-573 \mathrm{~K}$, they are always utilized in low temperature fuel cells [33]. In order to use them at the higher temperature, the materials are modified. Until now, the kinetic rate expressions of methanol reforming were investigated over various catalyst types such as $\mathrm{Cu} / \mathrm{ZnO} / \mathrm{Al}_{2} \mathrm{O}_{3}$ [33-35], $\mathrm{Cu} / \mathrm{ZnO}_{2} / \mathrm{CeO}_{2}[36]$ and $\mathrm{CuX}_{2} \mathrm{O}_{4}(\mathrm{X}=\mathrm{Fe}, \mathrm{Mn}, \mathrm{Al}, \mathrm{La})[37]$. 


\section{Reforming of Ethanol}

Ethanol is considered to be one of good hydrogen sources for fuel cells. In order to increase hydrogen productivity together with limit carbon monoxide, ethanol steam reforming (ESR) has been used. According to previous works [38-39], hydrogen can be produced via several pathways in the ESR system. However, there are only four major reactions, Eqs. (13)-(16), which are considered.

$$
\begin{array}{ll}
\text { Ethanol steam reforming: } & \mathrm{H}_{5} \mathrm{OH}+3 \mathrm{H}_{2} \mathrm{O} \leftrightarrow 6 \mathrm{H}_{2}+2 \mathrm{CO}_{2} ; \Delta \mathrm{H}_{\mathrm{rxn}}=174 \mathrm{~kJ} / \mathrm{mol} \\
\text { Ethanol decomposition: } & \mathrm{C}_{2} \mathrm{H}_{5} \mathrm{OH} \leftrightarrow \mathrm{H}_{2}+\mathrm{CO}+\mathrm{CH}_{4} ; \Delta \mathrm{H}_{\mathrm{rxn}}=49 \mathrm{~kJ} / \mathrm{mol} \\
\text { Water gas shift: } & \mathrm{CO}+\mathrm{H}_{2} \mathrm{O} \leftrightarrow \mathrm{H}_{2}+\mathrm{CO}_{2} ; \Delta \mathrm{H}_{\mathrm{rxn}}=-41 \mathrm{~kJ} / \mathrm{mol} \\
\text { Partial oxidation: } & \mathrm{C}_{2} \mathrm{H}_{5} \mathrm{OH}+0.5 \mathrm{O}_{2} \leftrightarrow 3 \mathrm{H}_{2}+\mathrm{CO} ; \Delta \mathrm{H}_{\mathrm{rxn}}=20 \mathrm{~kJ} / \mathrm{mol}
\end{array}
$$

There are a number of catalytic material categories that could be applied for ethanol stream reforming process. Akande et al. [40] investigated the ESR kinetic reactions on $\mathrm{Ni} / \mathrm{Al}_{2} \mathrm{O}_{3}$. Sahoo et al. [41] studied the kinetic of ESR over $\mathrm{Co} / \mathrm{Al}_{2} \mathrm{O}_{3}$. $\mathrm{LaNiO}_{3}$ perovskite [42], $\mathrm{Pt}_{1.5} \mathrm{Co}_{\times} / \mathrm{ZrO}_{2}$ [43] were also used for ESR

It should be noted that both $\mathrm{H}_{2}$ and $\mathrm{CO}$ can be consumed via electrochemical reaction in SOFC. Normally, a reformer is separated from the fuel cell. In the case of a high temperature fuel cell, the reformer is integrated with the cell in order to transfer the liberated heat from the fuel cell to the reformer, as known as autothermal operation. This system can reach 50-60\% efficiency and provides relatively high power density [18]. Therefore, the possible reforming concepts of SOFC are external and internal reforming configuration. Park et al. [13] developed mathematical model to compare the system behavior of both external and internal reforming high temperature fuel cell. Their simulation results shown that methane-reforming reaction and the water-gas shift reaction occurred simultaneously and the temperature was distributed uniformly. However, the overall system temperature of internal reforming design is higher. This is effected to reduce the cell resistance. Normally, there are two internal reforming SOFC designs; Direct Internal Reforming (DIR) and Indirect Internal Reforming (IIR).

\subsection{External Reforming Concept}

In this design, the reformer is separated from the fuel cell stack, as shown in Fig. 4. Thus, fuel is reformed to hydrogen in the reformer before introduced to the fuel cell chamber [20]. According to this operation, the heat liberated from fuel cell stack is not utilized so it is necessary to supply the heat toward the reformer. In order to use the waste heat, the anode gas is recycled. But the inlet fuel maybe diluted by the anode exit gases that leads to reduce the open circuit voltage [15, 44].

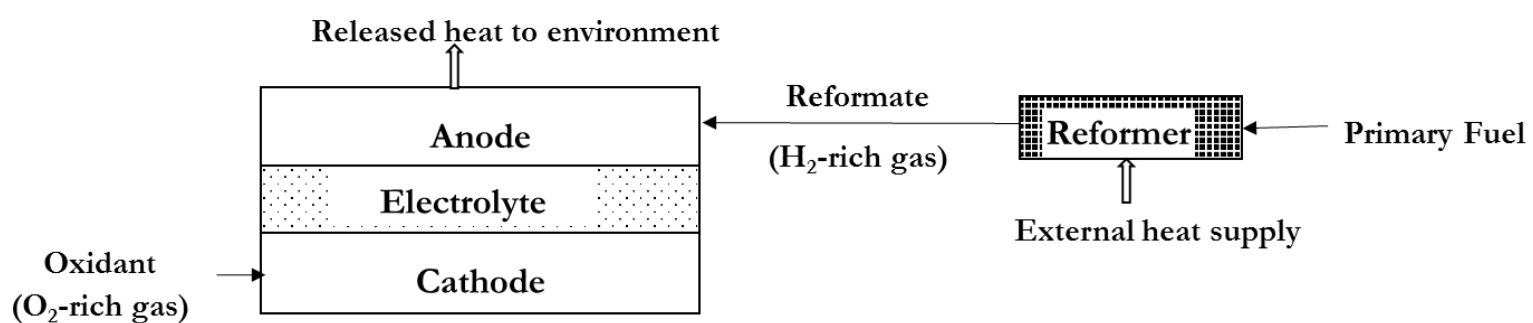

Fig. 4. External reforming fuel cell configuration.

\subsection{DIR-SOFC Concept}

Concerning DIR operation (Fig. 5), the primary fuel is converted directly at the anode surface, where syngas is generated and consumed simultaneously. Meanwhile, heat is also utilized and discharged at surface. Thus, the external heat requirement of the reformer and the cooling requirement of the fuel cells can be neglected. Compared to external reforming, internal reforming has many advantages: reduced system complication (as explained above) reduced system cost, and increased system efficiency [15]. This configuration causes two main problems. Firstly, the anode deactivation by carbon deposition which leads to decrease the system efficiency. Secondly, there is a large temperature gradient across the cell because of an extremely endothermic reforming reaction as known as the strong cooling effect, (Fig. 6(a)). Thus, high carbon resistant and durability properties are required for the anode material in DIR operation [14]. Other key parameters that must be considered, i.e. type of fuel, electro-catalytic activity, reactivity of production 
gases, and efficiency of respective fuel direct reaction of hydrocarbon on the electrode. However, the SOFC with DIR operation provides high fuel conversion and more uniform temperature distribution when compared with IIR-SOFC.

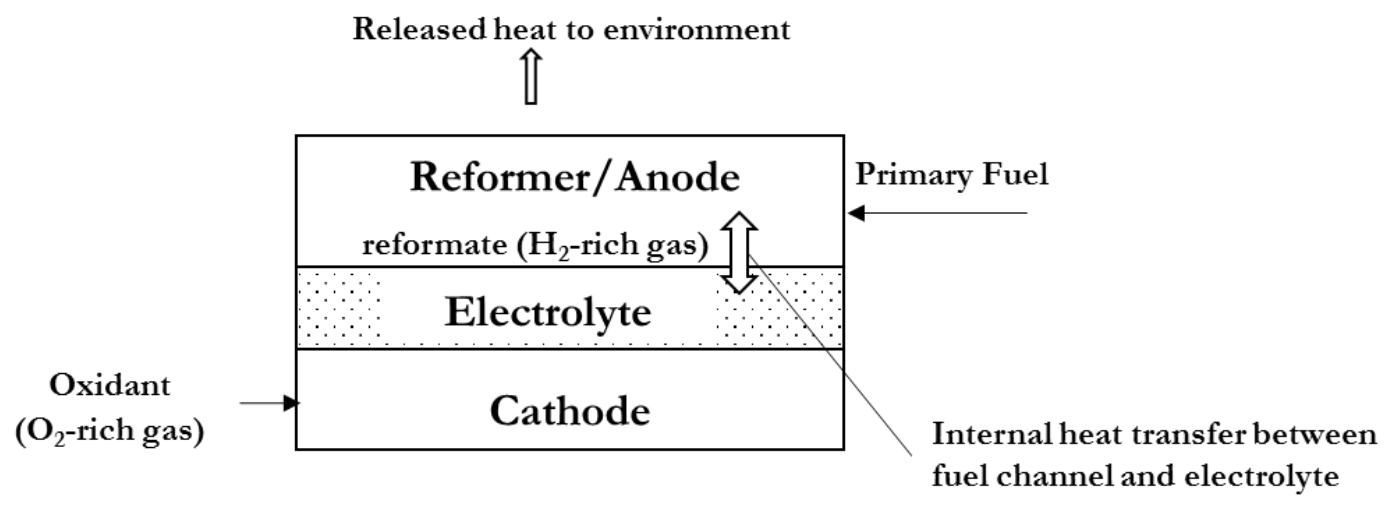

Fig. 5. Direct internal reforming fuel cell configuration.

\subsection{IIR-SOFC Concept}

For IIR-SOFC design, the catalytic reformer is not inside the fuel cell system but it is in close thermal contact with anode, Fig. 7. Moreover, the reforming catalyst and anode material can be optimized individually. The catalysis of internal reformer is depended on the type of primary fuel.

According to this configuration, primary fuel is reformed to syngas before fed to generate electricity at the anode side of the fuel cell. Thus, the endothermic reforming reaction takes place at the reformer in close thermal contact with the anode side of the fuel cell where an exothermic electrochemical reaction takes place. Although the reformer is adjacent to the cell stack, their physical environments do not get the direct influence to each other [44]. The main drawback of this configuration is the local mismatch between the rates of endothermic and exothermic reactions. This leads to a significant local temperature reduction near the entrance of the reformer, Fig. 6(b). This could result in mechanical failure due to thermally induced stresses. Furthermore, IIR system can be fabricated into planar and tubular designs. These had been proposed from several previous researchers. In IIR-planar configuration, the plate reformer is alternated with small cell packages so that the inlet fuel from each cell is fed to adjacent cells such as the integrated planar SOFC of Gardner et al. [45]. One of possible tubular design is the work of Aguiar et al. [46]. In this work, a reformer was the inner tube which was surrounded with the fuel cell.
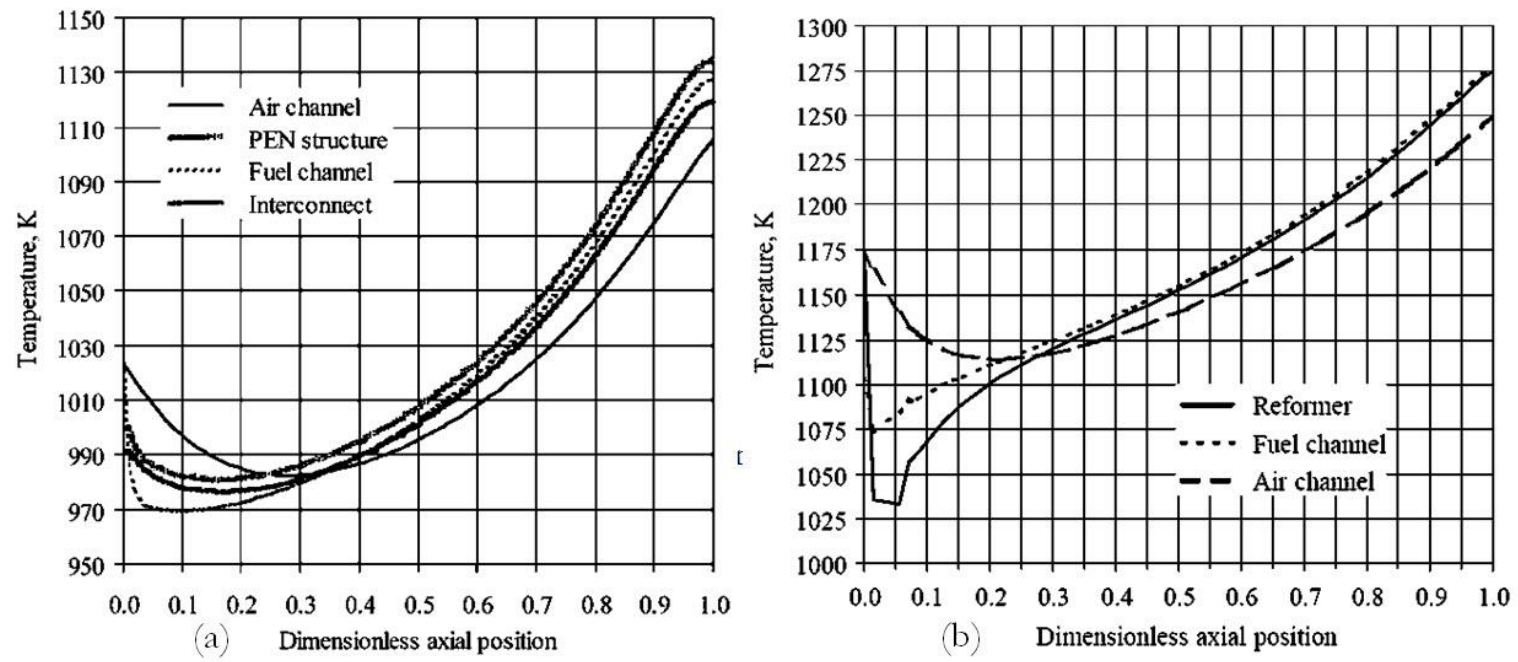

Fig. 6. The reforming, fuel channel, and air channel temperature profiles of (a) DIR-SOFC fueled by methane [47]; (b) IIR-SOFC fueled by methane [46]. 


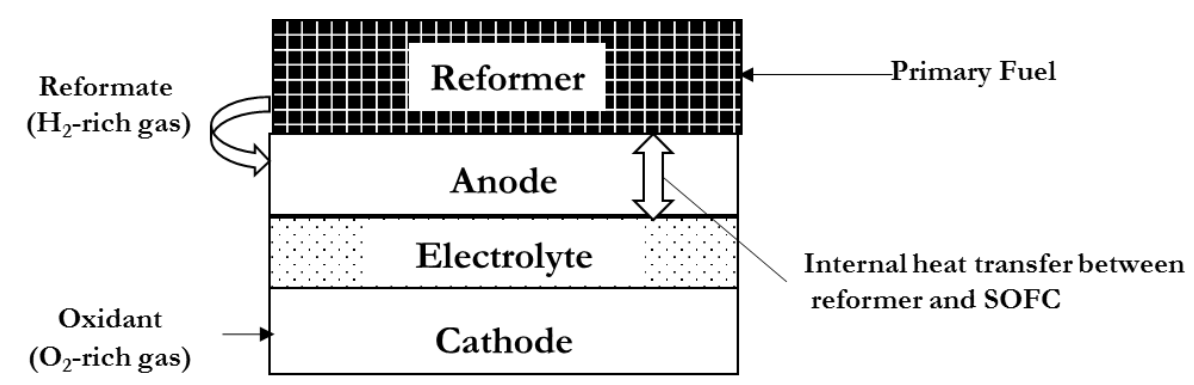

Fig. 7. Indirect internal reforming fell cell configuration.

Noted that SOFC is operated at high temperature. Thus, the thermal stress of the material is the major problem in SOFC development. The residual stress was the influence of thermal expansion mismatch of anode/electrolyte/cathode materials. This might be the main limitation for both DIR and IIR- SOFC operation. It can be seen that the IR-SOFC configuration has certain advantages; nevertheless, there are still some technical problems to overcome. As suggestion of Lim et al. [48], the temperature gradient was should not higher than $10 \mathrm{~K} / \mathrm{cm}$.

\section{Autothermal Solid Oxide Fuel Cell Design}

The autothermal operation has been of interest in education and industry during the last decade [24] Integration of regenerative and recuperative heat exchanger and reactor within one part of the equipment is the main concept of this operation. Its advantages are heat loss minimization and the less sensitivity to perturbations due to its natural adaptive [25]. The existing autothermal reactor contributions are based on different heat recovery systems: the reverse-flow reactor using direct or regenerative heat exchange and the counter-current fixed-bed reactor using indirect or recuperative heat exchange [25].The main application of these two designs is in the field of waste gas purification. This concept is currently applied to the thermal coupling of the endothermic and exothermic reactions in an autothermal multifunctional reactor. According to the review of Kolios et al. [24], the autothermal operation is possible only if the overall reaction is weakly to moderately exothermic. This is the first limitation on the coupling of the two reactions. There are three ways to achieve autothermal operation. If the reactants for both (endo- and exothermic) reactions are mixed and all the reactions run more or less in parallel, it is called "simultaneous operation". If the reactants are separated, the feed directions of endothermic and exothermic reaction can be in parallel (co-current) or in opposite side (counter-current) as called asymmetric and symmetric operation, respectively.

According to the literatures, the following phenomenon has been compiled: kinetic, thermodynamic, and electrochemical behaviors, which take place in the SOFC system, in order to predict the autothermal behavior.

\subsection{IR-SOFC Configuration}

Historically, the IR configuration had been developed for optimize the system efficiency and reduce the operating limitation such as life time of catalyst, structural material. The performance of IR design is normally investigated by using mathematical simulation technique. In the early stages of fuel cell modeling, simulations were developed with the isothermal-steady condition assumption. In order to achieve the real behavior of the fuel cell system, the mathematical equations became more complex. Then the model was developed under a non-isothermal steady condition assumption. Moreover, operating time also affected the system behavior; therefore, the dynamic model was also recognized.

In 1996, Ma et al. [49] simulated the methanol reforming reaction in an autothermal reactor. Combining three main reactions; methanol oxidation, methanol steam reforming reaction, and water gas shift. Onedimensional mathematical models were developed to investigate the performance of adiabatic dual-bed catalytic reactor systems with cylindrical and spherical geometries, as shown in Fig. 8. The simulation results showed that the spherical reactor, where $\mathrm{Pt}-\mathrm{Al}_{2} \mathrm{O}_{3}$ catalyst was in the inner sphere, has the most optimal geometry. The coaxial double-pipe design was portable for the small reactor volume. As economic 
perspective, the annular oxidation bed is more preferable. After that, the planar and tubular SOFC have been applied both DIR-SOFC and IIR SOFC approaches.

In 1999, the autothermal operation was also applied to electrochemical oxidation of SOFC by Neophytides et al. [50]. They investigated the dynamic operation of the electrochemical oxidation of $\mathrm{H}_{2}$ in planar monolithic SOFCs operating under forced periodic reverse- flow with different flow-patterns. They found that this reverse flow reactor provided more uniform concentration and temperature distribution than the co-current flow.

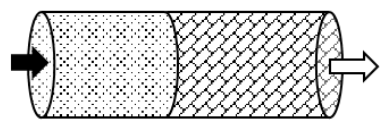

a) Dual fixed bed reactor

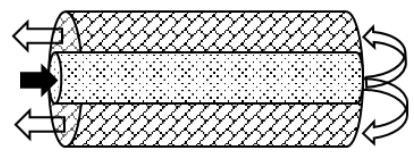

b) Coaxial cylindrical reactor I

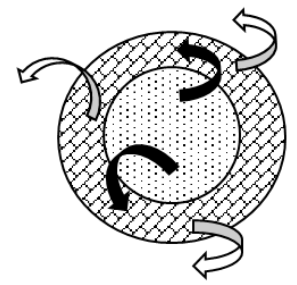

d) Concentric spherical reactor I
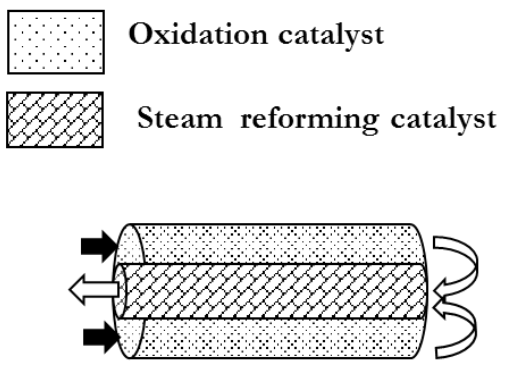

c) Coaxial cylindrical reactor II

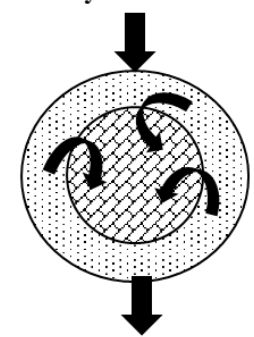

e) Concentric spherical reactor II

Fig. 8. Autothermal reactor schemes [49].

\subsection{DIR-SOFC Configuration and Operation}

As indicated above, the major limitation of DIR-SOFC configuration is large temperature gradient across the solid cell and carbon deposition at the anode material. Ni/YSZ is interested choice for anode DIRSOFC since none of carbon deposition over Ni/YSZ under methane and methanol steam reforming at high temperature (around $1273 \mathrm{~K}$ ). However, ethanol could not be completely reformed over anode $\mathrm{Ni} / Y S Z$. This is strongly affected to carbon formation over the anode [51-52]. Resini et.al. [53] suggested that ethanol is completely reformed over Ni-Co (25:25)/YSZ material. This could apply for DIR-SOFC technology.

Increasing the electrochemical reaction rate is one of interested way to reduce temperature gradient along the solid cell. Aguiar $e t$ al. [47] proposed the anode-supported intermediate temperature planar DIRSOFC as the alternative design. The advantages of the anode-supported SOFC are lower in ohmic losses compared with electrolyte supported SOFC. Thus, it could be operated at the intermediate temperature $(823 \mathrm{~K}-1073 \mathrm{~K})$ and fixable for wind range of material. The temperature difference $(-135 \mathrm{~K})$ at the entrance of the system was still presented in their simulation results.

After that Nikooyeh et al. [54] developed three-dimensional-dynamic model to study the temperature behavior of the anode-supported planar SOFC for DIR operation with anode exhaust gases recycling. This recycled gases are benefited to increase rate of electrochemical reaction and also retard the rate of carbon formation at the anode side. Nevertheless, the cooling temperature $(\sim 50 \mathrm{~K})$ still occurred at the first one fourth of the system. The maximum temperature gradient along the solid cell is $16.4 \mathrm{~K} / \mathrm{cm}$. As the work of Wang et al. [55], their model was developed to predict the residual stress in a single planar SOFC cell. They found that the residual thermal stress was reduced by decreasing the anode thickness or increasing the electrolyte thickness. The anode failure possibility was reduced when anode thickness was increased and the thickness of electrolyte was decreased.

Therefore, some researchers paid attention to apply electrolyte supported SOFC. Li et al. [56] simulated the behavior of planar DIR-SOFC under dynamic condition. They found the large temperature gradient 
(259 K) occurred along the solid electrodes and electrolyte. This might be resulted of low rate of hydrogen and carbon monoxide generation and consumption. In order to increase these two rates, Dokamaingam $e t$ al. [57] introduced tubular DIR-SOFC with inserting $\mathrm{Ni} / \mathrm{Al}_{2} \mathrm{O}_{3}$ catalyst rod. As seen in Fig. 9, methane and hydrogen conversion rates of conventional tubular DIR-SOFC is lower than DIR-SOFC tubular with inserted catalyst rod. The catalyst rod promoted the endothermic steam reforming of methane to hydrogen, which is efficiently consumed by exothermic electrochemical reaction at the anode. These caused the better temperature distribution for DIR-SOFC with inserting catalyst-rod and also provided significantly lower local cooling at the entrance of the fuel channel. In addition, electrical efficiency and power density improved (from $45.3 \%$ to $63.5 \%$ and $0.32 \mathrm{~A} / \mathrm{cm}^{2}$ to $0.45 \mathrm{~A} / \mathrm{cm}^{2}$ ) with remarkable lower carbon formation can be achieved compared to the conventional tubular DIR-SOFC. Furthermore, the average temperature gradient along the DIR-SOFC with inserted catalyst rod was within $8.3 \mathrm{~K} / \mathrm{cm}$.
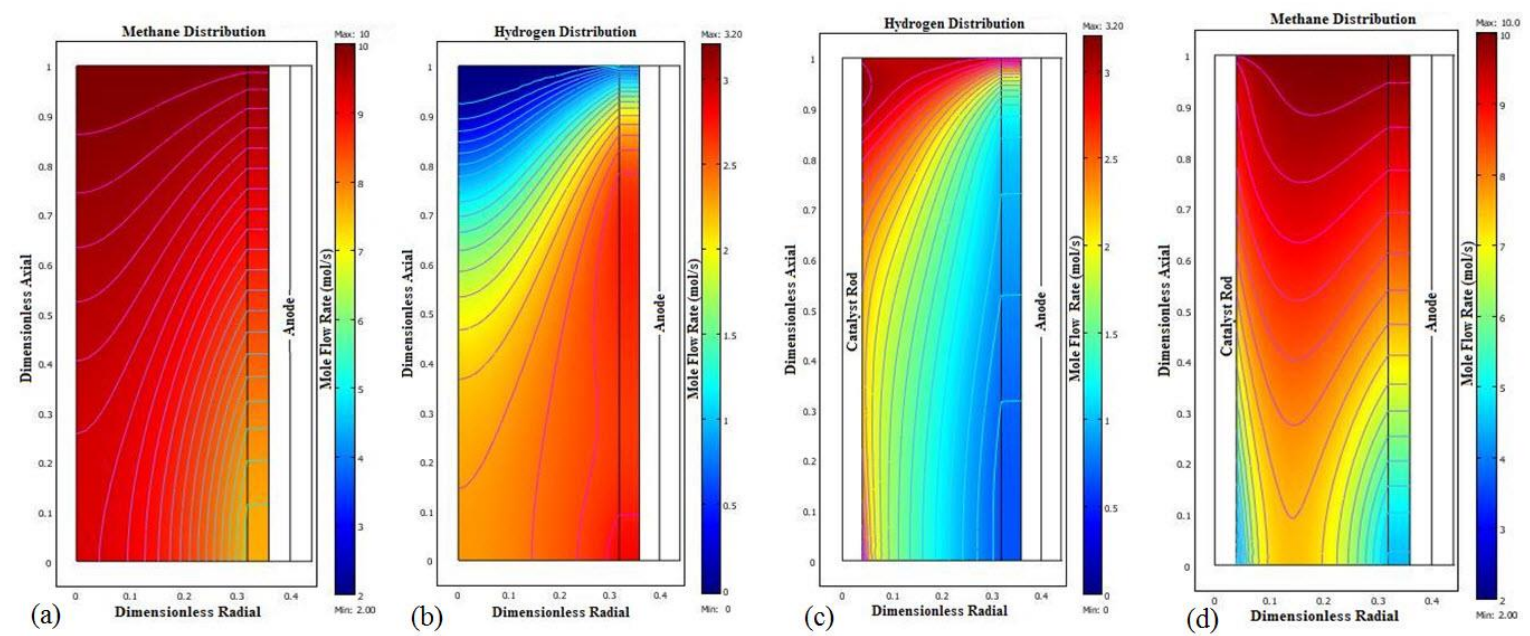

Fig. 9. Results from COMSOL $\AA$ represented the concentration profiles in the fuel channel of DIRSOFC systems (simulated at 1 bar with inlet $\mathrm{S} / \mathrm{C}$ ratio of 2). Concentration profiles of (a) methane and (b) hydrogen in the fuel channel in the conventional DIR-SOFC. Concentration profiles of (c) methane and (d) hydrogen in the fuel channel in the inserted catalyst rod DIR-SOFC [57].

Alternatively, a proton conducting SOFC (SOFC-H+) was studied under DIR condition. In 2013, the thermal and electrical behavior of DIR-SOFC-H+ stack model was predicted by integrating electrochemical model, kinetic model and thermodynamic model [58]. Under one-dimensional steady state assumption, the simulation results shown that carbon formation at the anode material is reduced by increasing the stream to carbon and oxygen to carbon feed ratios.

\subsection{IIR-SOFC Configuration and Operation}

Since the reformer is separated for the SOFC in IIR-SOFC configuration, the catalytic material in the reformer is chosen based on the primary fuel as indicated in section 3. Meanwhile, the solid cell is generally fabricated from Ni/YSZ anode, perovskite-based $\mathrm{LaMnO}_{3}$ cathode and yttria-stabilized zirconia (YSZ) electrolyte [4].

In 2002, Aguiar et al. [46] presented the modeling of tubular IIR-SOFC. This model was used to investigate the mismatch between the thermal load associated with the steam reforming rate and the local quantity of heat available from the fuel cell's reactions. They observed that the temperature across the cell is rapidly raised around $140 \mathrm{~K}$ at the first $5 \%$ of the length. As this main drawback of IIR-SOFC, other researchers proposed alternative IIR-SOFC configurations. In order to reduce the extreme of stream reforming reaction, amount of catalyst loading in the internal reformer should be reduced. Thus, Lim et al. [48] and Dokamaingam et al. [59] changed an internal reformer from fixed bed to coated wall configuration for planar and tubular IIR-SOFC, respectively. The benefits of coated-wall reformer with catalyst washcoated at inside surface are excellent heat transfer characteristics and low pressure drop across the reactor. In addition, the amount of catalyst per volume for the catalytic coated-wall reformer is lower than catalytic packed-bed reformer. Therefore, the extreme rate of reforming reaction was reduced by decreasing catalyst 
activity of the whole system. It was found that this changes was able to reduce the cooling spot at the entrance of the IIR-SOFC system. As the work of Lim et al. [48], the temperature was immediately dropped around $70 \mathrm{~K}$ near the entrance of the reformer. Meanwhile, Dokamaingam et al. [59] found that temperature is decreased around $89 \mathrm{~K}$ at the entrance of coated wall reformer compared to $143 \mathrm{~K}$ in the case of IIR-SOFC with packed-bed internal reformer.

\section{Conclusion}

In order to achieve the autothermal operation, SOFC could be integrated with reformer to optimize heat utilization between endothermic reforming reaction and exothermic electrochemical reaction. There are two approaches for this integration, DIR and IIR. Under this idea, conversion rates of primary fuels and hydrogen is highly influenced to temperature distribution in both DIR and IIR designs. However, rate of reforming reaction is more extreme than electrochemical reaction so the local mismatch temperature is still found in these two designs. Material cracking in the solid electrodes and electrolyte is resulted from his thermal stress. Several DIR and IIR designs are developed to optimize the heat utilization in the system. Most of them are designed to reduce the reforming reaction rate or increase rate of electrochemical reaction. In the case of DIR-SOFC, the electrochemical reaction rate is improved by increasing the thickness of anode material or adding the catalytic rod into the anode. Moreover, the catalyst rod is beneficial to reduce the carbon formation at the anode material. The average temperature gradient along the DIR-SOFC with inserted catalyst rod is lower than the critical criteria $(10 \mathrm{~K} / \mathrm{cm}$.). Meanwhile, pecked bed internal reformer of IIR-SOFC had been improved to coated wall internal reformer in order to reduce the extreme of reforming reactions. It was found that temperature gradient near the entrance of IIR-SOFC with internal coated wall internal reformer is not higher than the limitation. Moreover, IIR-SOFC is more flexible for various feedstocks because the reformer is separated from anode site. Comparing methane methanol and ethanol, a pecked bed tubular IIR-SOFC fueled by methanol provided the smoothest temperature distribution (reformer temperature decreases from 1173 to $1163 \mathrm{~K}$ ) [60] because methanol reforming reaction required the lowest supplied heat. For further work, it might be good to investigate temperature distribution of IIR-SOFC with coated wall internal reformer and DIR-SOFC with inserted catalyst rod when feed by difference feed stocks. It might be the alternative configuration for both DIRSOFC and IIR-SOFC operation.

\section{References}

[1] W. Wiyaratn, "Review on fuel cell technology for valuable chemicals and energy co-generation," Engineering Journal, vol. 14, no. 3, pp. 1-14, July 2010.

[2] M. Boder and R. Dittmeyer, "Catalytic modification of conventional SOFC anodes with a view to reducing their activity for direct internal reforming of natural gas," J. Power Sources, vol. 155, no. 1, pp. 13-22, Apr. 2006.

[3] C. O. Colpan, I. Dincer, and F. Hamdullahpur, "Thermodynamic modeling of direct internal reforming solid oxide fuel cells operating with syngas," Int. J. Hydrogen Energ., vol. 32, no. 7, pp. 787795, May 2007.

[4] N. Laosiripojana, W. Wiyaratn, W. Katkittipong, A. Arpornwichanop, A. Soottitantawat, and S. Assabumrungrat, "Reviews on solid oxide fuel cell technology," Engineering Journal, vol. 13, no. 1, pp. 65-83, Jan. 2009.

[5] J. Nielsen and J. Hjelm, "Impedance of SOFC electrodes: A review and a comprehensive case study on the impedance of LSM:YSZ cathodes," Electrochim. Acta, vol. 115, pp. 31-45, Jan. 2014.

[6] J. Patakangas, Y. Ma, Y. Jing, and P. Lund, "Review and analysis of characterization methods and ionic conductivities for low-temperature solid oxide fuel cells (LT-SOFC)," J. Power Sources, vol. 263, pp. 315-331, Oct. 2014.

[7] J. Wu and X. Liu, "Recent development of SOFC metallic interconnect," J. Mater. Sci. Tecbnol., vol. 26, no. 4, pp. 293-305, Apr. 2010.

[8] M. Liu, M. E. Lynch, K. Blinn, F. M. Alamgir, and Y. M. Choi, "Rational SOFC material design: new advances and tools," Mater. Today, vol. 14, no. 11, pp. 534-546, Nov. 2011.

[9] V. Lawlor, "Review of the micro-tubular solid oxide fuel cell (Part II: Cell design issues and research activities)," J. Power Sources, vol. 240, pp. 421-441, Oct. 2013. 
[10] X. Zhang, S. H. Chan, G. Li, H. K. Ho, J. Li, and Z. Feng, "A review of integration strategies for solid oxide fuel cells," J. Power Sources, vol. 195, no. 3, pp. 685-702, 2010.

[11] K. Wang, D. Hissel, M. C. Péra, N. Steiner, D. Marra, M. Sorrentino, C. Pianese, M. Monteverde, P. Cardone, and J. Saarinen, "A review on solid oxide fuel cell models," Int. J. Hydrogen Energ., vol. 36, no. 12, pp. 7212-7228, Jun. 2011.

[12] V. Lawlor, S. Griesser, G. Buchinger, A. G. Olabi, S. Cordiner, and D. Meissner, "Review of the micro-tubular solid oxide fuel cell: Part I. Stack design issues and research activities," J. Power Sources, vol. 193, no. 2, pp. 387-399, Sept. 2009.

[13] H.-K. Park, Y.-R. Lee, M.-H. Kim, G.-Y. Chung, S.-W. Nam, S.-A. Hong, T.-H. Lim, and H.-C. Lim, "Studies of the effects of the reformer in an internal-reforming molten carbonate fuel cell by mathematical modeling," J. Power Sources, vol. 104, no.1, pp. 140-147, Jan. 2002.

[14] J.-M. Klein, Y. Bultel, S. Georges, and M. Pons, "Modeling of a SOFC fuelled by methane: From direct internal reforming to gradual internal reforming," Chem. Eng. Sci., vol. 62, no. 6, pp. 1636-1649, Mar. 2007.

[15] J. Larminie, and A. Dicks, "Operational fuel cell voltages," in Fuel Cell Systems Explained, 2nd ed. John Wiley \& Sons Ltd., 2003.

[16] P.-W. Li and M. K. Chyu, "Simulation of the chemical/electrochemical reactions and heat/mass transfer for a tubular SOFC in a stack," J. Power Sources, vol. 124, no. 2, pp. 487-498, Nov. 2003.

[17] T. X. Ho, P. Kosinski, A. C. Hoffmann, and A. Vik, "Numerical analysis of a planar anode-supported SOFC with composite electrodes," Int. J. Hydrogen Energ., vol. 34, no. 8, pp. 3488-3499, May 2009.

[18] R. A. Vargas, R. Chiba, M. Andreoli, and E. S. M. Seo, "Síntese e caracterização dos pós de Nd1xSrxMnO3 e La1-xSrxCo1-yFeyO3," Matéria (Rio de Janeiro), vol. 12, no.1, pp. 8-21, 2007.

[19] EG\&G Technical Services Inc., "Solid oxide fuel cells," in Fuel Cell Handbook, 7th ed. Virginia: DIANE Publishing, 2004.

[20] W. Vielstich, H. A. Gasteiger, and A. Lamm, "Internal reforming," in Handbook of Fuel Cells. John Wiley \& Sons, 2003, pp. 1059-1069.

[21] E. H. Pacheco, D. Singha, P. N. Hutton, N. Patel and M. D. Mann, "A macro-level model for determining the performance characteristics of solid oxide fuel cells," J. Power Sources, vol. 138, no. 1-2, pp. 174-186, Nov. 2004.

[22] D. Sánchez, R. Chacartegui, A. Munoz, and T. Sánchez, "Thermal and electrochemical model of internal reforming solid oxide fuel cells with tubular geometry," J. Power Sources, vol. 160, no. 2, pp. 1074-1087, Oct. 2006.

[23] R. Suwanwarangkul, E. Croiset, M. W. Fowler, P. L. Douglas, E. Entchev, and M. A. Douglas, "Performance comparison of Fick's, dusty-gas and Stefan-Maxwell models to predict the concentration overpotential of a SOFC anode," J. Power Sources, vol. 122, no. 1, pp. 9-18, July 2003.

[24] G. Kolios, J. Frauhammer, and G. Eigenberger, "Autothermal fixed-bed reactor concepts," Chem. Eng. Sci., vol. 55, no. 24, pp. 5945-5967, Dec. 2000.

[25] J. Frauhammer, G. Eigenberger, L. V. Hippel, and D. Arntz, "A new reactor concept for endothermic high-temperature reactions," Chem. Eng. Sci., vol. 54, no. 15-16, pp. 3661-3670, July 1999.

[26] J. Xu and G. F. Froment, "Methane steam reforming, methanation and water-gas shift: I. intrinsic kinetics," A.I.Ch.E. Journal, vol. 35, no. 1, pp. 88-96, Jan. 1989.

[27] D. L. Hoang, S. H. Chan, and O. L. Ding, "Kinetic and modelling study of methane steam reforming over sulfide nickel catalyst on a gamma alumina support," Chem. Eng. J., vol. 112, no. 1, pp. 1-11, Sept. 2005.

[28] K. Ahmed and K. Foger, "Kinetics of internal steam reforming of methane on Ni/YSZ-based anodes for solid oxide fuel cells," Catal. Today, vol. 63, no. 2-4, pp. 479-487, Dec. 2000.

[29] A. L. Dicks, K. D. Pointon, and A. Siddle, "Intrinsic reaction kinetics of methane steam reforming on a nickel/zirconia anode," J. Power Sources, vol. 86, no. 1-2, pp. 523-530, Mar. 2000.

[30] S. Y. Lee, H. Lim, and H. C. Woo, "Catalytic activity and characterizations of $\mathrm{Ni} / \mathrm{K}_{2} \mathrm{Ti}_{\mathrm{x}} \mathrm{O}_{5}-\mathrm{Al}_{2} \mathrm{O}_{3}$ catalyst for steam methane reforming," Int. J. Hydrogen Energ., vol. 39, no. 31, pp. 17645-17655, Oct. 2014.

[31] M. H. Halabi, M. H. J. M. de Croon, J. van der Schaaf, P. D. Cobden, and J. C. Schouten, "Low temperature catalytic methane steam reforming over ceria-zirconia supported rhodium," Appl. Catal. A- Gen., vol. 389, no. 1-2, pp. 68-79, Dec. 2010.

[32] S. R. Samms and R. E. Savinell, "Kinetics of methanol-steam reformation in an internal reforming fuel cell," J. Power Sources, vol. 112, no. 1, pp. 13-29, Oct. 2002. 
[33] L. Ma, C. Jiang, A. A. Adesina, D. L. Trimm, and M. S. Wainwright, "Simulation studies of autothermal reactor system for $\mathrm{H} 2$ production from methanol steam reforming," Chem. Eng. J. Bioch Eng., vol. 62, no. 2, pp. 103-111, May 1996.

[34] B. A. Peppley, J. C. Amphlett, L. M. Kearns, and R. F. Mann, "Methanol-steam reforming on $\mathrm{Cu} / \mathrm{ZnO} / \mathrm{Al}_{2} \mathrm{O}_{3}$. Part I: the reaction network," Appl. Catal. A-Gen., vol. 179, no.1-2, pp. 21-29, Apr. 1999.

[35] J. E. Park, S. D. Yim, C. S. Kim, and E. D. Park, "Steam reforming of methanol over $\mathrm{Cu} / \mathrm{ZnO} / \mathrm{ZrO}_{2} / \mathrm{Al}_{2} \mathrm{O}_{3}$ catalyst," Int. J. Hydrogen Energ., vol. 39, no. 22, pp. 11517-11527, July 2014.

[36] A. Mastalir, B. Frank, A. Szizybalski, H. Soerijanto, A. Deshpanda, M. Niederberger, R. Schomacker, R. Schlogl, and T. Ressler, "Steam reforming of methanol over $\mathrm{Cu} / \mathrm{ZnO}_{2} / \mathrm{CeO}_{2}$ catalysts: a kinetic study," J. Catalysis, vol. 230, no. 2, pp. 464-475, Mar. 2005.

[37] Y.-H. Huang, S.-H Wang, A.-P. Tsai, and S. Kameoka, "Reduction behaviors and catalytic properties for methanol steam reforming of $\mathrm{Cu}$-based spinel compounds $\mathrm{CuX2O} 4$ (X=Fe, Mn, Al, La)," Ceram. Int., vol. 40, no. 3, pp. 4541-4551, Apr. 2014.

[38] A. Akande, A. Aboudheir, R. Idem, and A. Dalai, "Kinetic modeling of hydrogen production by the catalytic reforming of crude ethanol over a co-precipitated $\mathrm{Ni}-\mathrm{Al}_{2} \mathrm{O}_{3}$ catalyst in a packed bed tubular reactor," Int. J. Hydrogen Energ., vol. 31, no. 12, pp. 1707-1715, Sept. 2006.

[39] D. R. Sahoo, S. Vajpai, S. Patel, and K. K. Pant, "Kinetic modeling of steam reforming of ethanol for the production of hydrogen over $\mathrm{Co} / \mathrm{Al}_{2} \mathrm{O}_{3}$ catalyst," Chem. Eng. J., vol. 125, no. 3, pp. 139-147, June 2007.

[40] A. Akande, A. Aboudheir, R. Idem, and A. Dalai, "Kinetic modeling of hydrogen production by the catalytic reforming of crude ethanol over a co-precipitated catalyst in a packed bed tubular reactor," Int. J. Hydrogen Energ., vol. 31, no. 12, pp. 1707-1715, Sept. 2006.

[41] D. R. Sahoo, S. Vajpai, S. Patel, and K. K. Pant, "Kinetic modeling of steam reforming of ethanol for the production of hydrogen over $\mathrm{Co} / \mathrm{Al}_{2} \mathrm{O}_{3}$ catalyst," Chem. Eng. J., vol. 125, no. 3, pp. 139-147, Jan. 2007.

[42] K.-H. Lin, C.-B. Wang, and S.-H. Chien, "Catalytic performance of steam reforming of ethanol at low temperature over LaNiO3 perovskite," Int. J. Hydrogen Energ., vol. 38, no. 8, pp. 3226-3232, Mar. 2013.

[43] J. Y. Z. Chiou, C.-L. Lee, K.-F. Ho, H.-H Huang, S.-W. Yu, and C.-B Wang, "Catalytic performance of Pt-promoted cobalt-based catalysts for the steam reforming of ethanol," Int. J. Hydrogen Energ., vol. 39, no. 11, pp. 5653-5662, Apr. 2014.

[44] R. Fellows, "A novel configuration for direct internal reforming stacks," J. Powver Sources, vol. 71, no. 12, pp. 281-287, Mar., 1998.

[45] F. J. Gardner, M. J. Day, N. P. Brandon, M. N. Pashley, and M. Cassidy, "SOFC technology development at Rolls-Royce," J. Power Sources, vol. 86, no. 1-2, pp. 122-129, Mar. 2000.

[46] P. Aguiar, D. Chadwick, and L. Kershenbaum, "Modelling of an indirect internal reforming solid oxide fuel cell," Chem. Eng. Sci., vol. 57, no. 10, pp. 1665-1677, May 2002.

[47] P. Aguiar, C. S. Adjiman, and N. P. Brandon, "Anode-supported intermediate temperature direct internal reforming solid oxide fuel cell. I: model-based steady-state performance," J. Power Sources, vol. 138, no. (1-2), pp. 120-136, Nov. 2004.

[48] L. T. Lim, D. Chadwick, and L. Kershenbaum, "Achieving autothermal operation in internally reformed solid oxide fuel cells: Simulation studies," Ind. Eng. Chem. Res., vol. 44, pp. 9609-9618, Aug. 2005.

[49] L. Ma, C. Jiang, A. A. Adesina, D. L. Trimm, and M. S. Wainwright, "Simulation studies of autothermal reactor system for $\mathrm{H}_{2}$ production from methanol steam reforming," Chem. Eng. J. Bioch. Eng., vol. 62, no. 2, pp. 103-111, May 1996.

[50] S. G. Neophytides, "The reversed flow operation of a cross-flow solid oxide fuel cell monolith," Chem. Eng. Sci., vol. 54, no. 2, pp. 4603-4613, Oct. 1999.

[51] N. Laosiripojana and S. Assabumrungrat, "Catalytic steam reforming of methane, methanol, and ethanol over Ni/YSZ: The possible use of these fuels in internal reforming SOFC," J. Power Sources, vol. 163, no. 2, pp. 943-951, Jan. 2007.

[52] P. Leone, A. Lanzini, G. A. Ortigoza-Villalba, and R. Borchiellini, "Operation of a solid oxide fuel cell under direct internal reforming of liquid fuels," Chem. Eng. J., vol.191, pp. 349-355, May 2012.

[53] C. Resini, M. C. H. Delgado, S. Presto, L. J. Alemany, P. Riani, R. Marazza, G. Ramis, and G. Busca, "Yttria-stabilized zirconia (YSZ) supported Ni-Co alloys (precursor of SOFC anodes) as catalysts for the steam reforming of ethanol," Int. J. Hydrogen Energ., vol. 33, no.14, pp. 3728-3735, July 2008. 
[54] K. Nikooyeh, A. A. Jeje, and J. M. Hill, "3D modeling of anode-supported planar SOFC with internal reforming of methane," J. Power Sources, vol. 171, no. 2, pp. 601-609, Sept. 2007.

[55] L. Wang, H. Zhang, and S. Weng, "Modeling and simulation of solid oxide fuel cell based on the volume-resistance characteristic modeling technique," J. Power Sources, vol. 177, no. 2, pp. 579-589, Mar. 2008.

[56] J. Li, G.-Y. Cao, X.-J. Zhu, and H.-Y. Tu, "Two-dimensional dynamic simulation of a direct internal reforming solid oxide fuel cell,” J. Power Sources, vol. 171, no. 2, pp. 585-600, Sept. 2007.

[57] P. Dokamaingam, N. Laosiripojana, A. Soottitantawat, and S. Assabumrungrat, "Alternative concept for SOFC with direct internal reforming operation: Benefits from inserting catalyst rod," AIChE J., vol. 56, no. 6, pp. 1639-1650, Jun. 2010.

[58] A. Arpornwichanop and Y. Patcharavorachot, "Investigation of a proton-conducting SOFC with internal autothermal reforming of methane," Chem. Eng. Res. Des., vol. 91, no. 8, pp. 1508-1516, Aug. 2013.

[59] P. Dokamaingam, S. Assabumrungrat, A. Soottitantawat, I. Sramala, and N. Laosiripojana, "Modeling of SOFC with indirect internal reforming operation: Comparison of conventional packed-bed and catalytic coated-wall internal reformer," Int. J. Hydrogen Energ., vol. 34 , no. 1, pp. 410-421, Jan. 2009.

[60] P. Dokmaingam, S. Assabumrungrat, A. Soottitantawat, and N. Laosiripojana, "Modelling of tubulardesigned solid oxide fuel cell with indirect internal reforming operation fed by different primary fuels," J. Power Sources, vol. 195 , no. 1, pp. 68-78, Jan. 2010. 
